\title{
Understanding Women Perspective on Smoke-Free Policy
}

\author{
Krisna Puji Rahmayanti ${ }^{1}$, Murwendah ${ }^{2}$, Arfah Habib Saragih ${ }^{3}$
}

krisnarahmayanti@ui.ac.id ${ }^{1}$, murwendah09@ui.ac.id ${ }^{2}$, arfah.habib11@ui.ac.id ${ }^{3}$

\author{
Faculty of Administrative Science, Universitas Indonesia
}

\begin{abstract}
This study aims to analyze the women's right perspective to the policy. This is a qualitative study. This research conducts two focus group discussion to collect data. Using women's right perspective of World Health Organization Framework Convention on Tobacco Control, this study triangulates primary and secondary data. Based on the MPOWER perspective, there is no national or local government smoke-free policy which underline the urgency to protect women as active or passive smokers. Smoke-free policy in Indonesia does not explicitly gender sensitive. Even though a robust smoke-free policy which has women's right perspective is limited, but there are several conditions which indicate the protection of women from the danger of tobacco-use. In the national level, there is a regulation about pictorial health warning with specific information about the danger of tobacco-use to pregnant women. Also, the focus group discussion found that all respondents support the implementation of the smoke policy. All of the respondents understand the urgency of the smoke-free policy. The informants who are women, in this case, are the secondhand smokers who have high motivation to solve the problem and save their family members from the danger of the tobacco-use.

Keywords: smoke-free policy; women; MPOWER
\end{abstract}

\section{Introduction}

The number of smokers in Indonesia is increasing. The number of smoke prevalence make Indonesia as the third highest smokers in the world after China and India [1]. Indonesia is the country with the highest smoke prevalence among men compared to nine other countries in South and Southeast Asian [2]. The problem of smokers in Indonesia is not only for adult smokers but also for children and teenage smokers.

Almost a decade the number of smoke prevalence among teenagers in Indonesia is increasing. Between 2007 to 2018, the smoke prevalence in teenager age between 10 to 18 years old is always increasing that is from $7.2 \%$ [3] to $8.8 \%$ [4] to $9.1 \%$ [5]. The increasing number of child smokers indicate that children become the target of smoker replacement as they become a potential group to be active smokers. Also, children have a high risk to be passive smokers.

Besides children and teenager, women are the second group who have a risk as the victim of active smoker recruitment and smoke exposure. There is a relatively low prevalence of smoking among women in Indonesia since several decades ago [6]. Until recently, the smoke prevalence of women in Indonesia reaches 4.8\% [5]. Even the situation in Indonesia is very problematic specially to invite women as new smokers, but there has been advertisement or strategy to promote consumption among women [7, p. 99]. Besides that, women are six times more susceptible to be the secondhand smokers at home [5]. This number shows that the danger of smoke exposure is higher in women.

Both as active and passive smokers, smoking is harmful to men and women, and the impact make women more susceptible. There are several types of research which underline the harmful effect of cigarette [8] [9]. The danger of smoking is higher to the pregnant women [10] [11] [12]. Both as an active or passive smoker, women also have a risk to get higher economic burden due to smoking-related diseases which also increase mortality of women. 
The smoke free policy is one of policy that aims to decrease smokers and smoke exposure to secondhand smokers. Several studies prove that smoke-free policy is essential to attain these aims [13] [14] [15]. Indonesia enacted smoke free policy through the Health Law in 2009 and the Government Regulation No 109 Year 2012. As a policy that control smoking in public places, this policy shows the changing paradigm of the executive which not only focus on income generated from tobacco tax but also understand the urgency to increase health promotion as a mean of tobacco control [16, p. 328]. Considering the risk of the women as active or passive smokers in Indonesia and the implementation of smoke free policy, this study aims to analyze the women perspective of the smoke-free policy. Using MPOWER package in World Health Organization (WHO) Framework Convention on Tobacco Control (FCTC), this study will discuss the current condition of the protection to the women through smoke-free policy and the empirical evidence in the community.

\section{Method}

This study employed qualitative data collection of focus group discussion. There are two focus group discussions in May and October 2018 to collect data. The investigation started by inviting 28 members of the community who are all women to join the discussion. Then, in the second discussion, this study invited 18 persons who came from village staff, teachers, students, and non-government organization. All of data collection were conducted in Tapos Village, Depok City, and West Java Indonesia which already implement smoke-free policy based on local government regulation. The researchers in this study play a role as consultants to the community. This study identifies the perspective of society to a smoke-free policy based on women's perspective which include monitor tobacco-use by gender and ensure that prevention policies are gender sensitive (Article 20 of the WHO FCTC), protect girls and women of all ages from tobacco smoke (Article 8 of the WHO FCTC), offer help to assist women in quitting tobacco-use (Article 14 of the WHO FCTC), warn women and girls about the dangers of tobacco through gender-sensitive information and communication strategies (Articles 1 and 12 of the WHO FCTC), enforce bans on tobacco advertising, promotion, and sponsorship by empowering women to identify and counter these influences (Article 13 of the WHO FCTC), and raise taxes on tobacco with the active participation of women leaders (Article 6 of the WHO FCTC).

This study use women perspective in MPOWER package of WHO FCTC. The WHO FCTC does not explicitly refer to gender equality, but there are several indicators based on women's right lens which correspond WHO FCTC [17]. All of the data (primary and secondary) are collected to analyze all of the condition based on these indicators. The secondary data is essential in this study to give macro perspective and find current smoke-free implementation portrait.

\section{Result and Discussion}

This study analyses the understanding of people about gender perspective in smoke-free policy. This discussion consists of the elaboration of current policy portrait in Indonesia using MPOWER package in WHO FCTC through women's right lens. The women perspective about the framework based on two focus group discussion which involves both men and women. Not only has the elaboration of the discussion, this study analyses the secondary data to strengthen the understanding of women's perspective on smoke-free policy.

Firstly, the existence of prevention policies which are gender sensitive. This indicator underlines the urgency to provide tobacco control policy based on gender-based information. Currently, Indonesia national monitoring system has observed the smoke prevalence both for men and women. However, the smoke-free policy as one of prevention policy in national level 
and also city level (Depok City) does not distinguish special treatment for men or women because of the number of smokers. Moreover, the high number of men who are smokers often become the main attention formally or culturally. The first focus group discussion which was attended by women participants stated that they were not active smokers, but some of them are passive smokers. They also stated that their family members, who are men, are smokers. This condition implies that even though there is a high number of men who smokers but there is also a risk for women as passive smokers. The regulation to prevent tobacco-use and smoke exposure need to understand this problem.

Secondly, there is a regulation that protects girls and women of all ages from tobacco smoke. In the smoke-free policy (national or local level), the government prohibit smoking in public spaces to protect people from smoke exposure include women. However, several participants of the discussion (men or women) mentioned that there is no strong law enforcement which makes them often become victims of the smoke exposure in the public spaces such as public transportation (local term angkot).

Even though there is still a challenge to protect women through regulation, the government has underlined the urgency to protect pregnant women. The government through the Government Regulation No 109 Year 2012 specifically stress that the tobacco industry needs to put a health warning in cigarette package which includes the statement of the harmful effect of tobacco-use to pregnant women. The protection to pregnant women is not a new movement of the executive since the government has mentioned about the danger of tobacco-use for women especially for pregnant women through the Government Regulation No 81 Year 1999. In our first discussion, all the respondents who are all women agree to warn smokers who are not abide the smoke-free policy and give a strong statement to their family members to quit smoking. This condition indicates that to attain a smoke-free environment, women play an essential role in controlling tobacco-use and preventing their family members from being the secondhand smokers. All of the women participants are the secondhand smokers that have high motivation to solve the problem and save their family members from the danger of the tobacco-use.

Thirdly, there is an offer to help and assist women to quit tobacco-use. Ministry of health has provided quit line for men and women who want to quit smoking. However along with smoke-free policy implementation, there is no special treatment for women to quit smoking. This program gives the same treatment to both men and women.

Fourthly, there is a warning to women and girls about the dangers of tobacco through gender-sensitive information and communication strategies. The focus group discussion found that all of the respondents understand the danger of tobacco consumption. However, they though that information and communication about the danger of the tobacco-use specifically for women is very limited. Even though there is limited campaign about this but there are many tobacco control campaigns from non-government organization which already increase the awareness of the society about the danger of tobacco-use. For example, there was collaboration between Komnas Pengendalian Tembakau (National Commision on Tobacco Control) and PT Transjakarta which post a gender-sensitive poster in public transportation.

Fifthly, enforce bans on tobacco advertising, promotion, and sponsorship by empowering women to identify and counter these influences. Meanwhile, several researchers found that plain packaging is an effective instrument to smoke cessation [18], Indonesia has not adopted this intervention. Current regulation bans tobacco advertisement before $09.30 \mathrm{am}$, but this regulation does not filter news or media coverage related to the tobacco industry before this time which makes media coverage about tobacco industry activities are still common. Besides that, the outdoor advertisement also still dominates public spaces. There are only several local 
governments such Jakarta Province, Kulon Progo Regency, or Bogor City who have banned outdoor advertisement of tobacco industry.

Furthermore, the targeted community agree that they need to involve in the tobacco control campaign in their community. They invite the other actors such as academician, nongovernment organization, and private sector to create an innovative campaign activity which empower women and men. Even though the community propose a gender-neutral activity but they specifically mention about the urgency to create this innovative activity for children and men as children are susceptible as new smokers and men in the area which mostly are smokers often smoking together while chatting in their social activities such as religious ritual or community meeting (rapat or arisan).

Sixthly, raise taxes on tobacco with the active participation of women leaders. In our fist discussion, all of the women participants write a letter to President and Minister of Finance in order to increase the price of cigarette through raising tobacco taxes. In the second discussion, there is a male participant who urge the raise of tobacco taxes in Indonesia which will increase the price per unit of cigarette pack. In the national level, there are also many movements which lead by women leaders such as include former health ministry and current health ministry to support the government to increase tobacco tax this year. However, recent statement of the government stated that there will be no increase of the tobacco taxes this year due to election. This development makes tobacco control activist include women leader from several organizations take action and send protest to the government.

\section{Conclusion}

The study found that smoke-free policy does not explicitly refer to the gender perspective. The smoke-free policy as a preventive policy protect both men and women in public spaces. The focus group discussion underlines several problems such as the urgency of law enforcement and protection to the women from the danger of secondhand smokers. All the respondents understand the urgency of smoke-free policy and several indications of tobacco control movements from several actors (government and non-government) prove that as a genderneutral policy, the enactment and implementation of smoke-free policy is important particularly to raise taxes to increase price per packs of cigarettes and ban tobacco industry advertising, promotion, and sponsorship.

Acknowledgment. This study is a part of the output of Community Development (Pengabdian Masyarakat) Grant 2018 funded by the Directorate of Research and Community Service of Universitas Indonesia.

\section{References}

[1] Ministry of Health Republic of Indonesia, „Merokok Tak Ada Untung Banyak Sengsaranya," Ministry of Health Republic of Indonesia, [Online]. Available: http://www.depkes.go.id/article/print/17041300002/merokok-tak-ada-untung-banyaksengsaranya.html. [Cit. 15 November 2018].

[2] C. T. Sreeramareddy, P. M. S. Pradhan, I. A. Mir a S. Sin, „Smoking and smokeless tobacco use in nine South and Southeast Asian countries: prevalence estimates and social determinants from Demographic and Health Surveys.," Population health metrics, zv. 12, \%1. vyd.1, p. 22, 2014.

[3] Ministry of Health Republic of Indonesia, „Riset Kesehatan Dasar,“ Ministry of Health Republic of Indonesia, Jakarta, 2013. 
[4] Ministry of Health Republic of Indonesia, „Survei Indikator Kesehatan,“ Ministry of Health Republic of Indonesia, Jakarta, 2016.

[5] Ministry of Health Republic of Indonesia, „Riset Kesehatan Dasar,“ Ministry of Health Republic of Indonesia, Jakarta, 2018.

[6] C. Best, K. Sun, S. De Pee, Sari M, M. Bloem a R. Semba, „Paternal smoking with increased risk of child malnutrition among poor urban families in Indonesia," Tobacco Control, zv. 17, \%1. vyd.1, pp. 38-45, 2008.

[7] S. Lawrence a J. Collin, „Competing with kreteks: transnational tobacco companies, globalisation, and Indonesia,“ Tobacco control, zv. 13, \%1. vyd.Suppl 2, pp. ii96-ii103., 2004.

[8] G. Bahrami, M. V. Væth, L. Kirkevang, A. Wenzel a F. Isidor, „The impact of smoking on marginal bone loss in a 10-year prospective longitudinal study, “ Community dentistry and oral epidemiology, zv. 45, \%1. vyd.(1), pp. 59-65., 2017.

[9] M. Śliwińska-Mossoń a H. Milnerowicz, „The impact of smoking on the development of diabetes and its complications," Diabetes and Vascular Disease Research, zv. 14, \%1. vyd.4, pp. 265-276., 2017.

[10] J. K. Phillips, J. M. Skelly, S. E. King, I. M. Bernstein a S. T. Higgins, „Associations of maternal obesity and smoking status with perinatal outcomes, " The Journal of MaternalFetal \& Neonatal Medicine, zv. 31, \%1. vyd.12, pp. 1620-1626., 2018.

[11] E. Raymond a J. Mills, „Placental abruption: maternal risk factors and associated condition," Acta Obstetricia et Gynecologica Scandinavica, zv. 11, pp. 633-639, 1997.

[12] K. Wisborg, T. B. Henriksen, M. Hedegaard a N. Jergen, ,Smoking during pregnancy and preterm birth, “ An International Journal of Obstetrics \& Gynaecolog, zv. 103, \%1. vyd.8, pp. 800-805., 1996.

[13] Partnership for Prevention, „Smoke-free Policies: Establishing a Smoke-Free Ordinance to Reduce Exposure to Secondhand Smoke in Indoor Worksites and Public Places: An Action Guide," Partnership for Prevention, Washington DC, United States of America, 2007.

[14] Task Force on Community Preventive Services, „Recommendations regarding interventions to reduce tobacco use and exposure to environmental tobacco smoke,“ American Journal of Preventive Medicine, zv. 20, \%1. vyd.2, pp. 10-15, 2001.

[15] M. R. Kaufman, A. P. Merrit, R. Rimbatmaja a J. E. Cohen, „'Excuse me, sir. Please don’t smoke here'. A qualitative study of social enforcement of smoke-free policies in Indonesia," Health Policy and Planning, zv. 30, \%1. vyd.8, pp. 995-1002, 1 October 2015.

[16] S. Barraclough, „Women and tobacco in Indonesia,“ Tobacco Control, zv. 8, \%1. vyd.3, pp. 327-332, 1999.

[17] World Health Organization, „Gender, women, and the tobacco epidemic,“ World Health Organization, Manila, Philippines, 2010.

[18] P. Jha a R. Peto, „Global effects of smoking, of quitting, and of taxing tobacco,“ New England Journal of Medicine, zv. 370, \%1. vyd.1, pp. 60-68, 2014. 